\title{
PELATIHAN MEMBUAT VIDEO PEMBELAJARAN YANG INTERAKTIF DAN KONSTRUKTIF UNTUK GURU MATEMATIKA SMP
}

\section{Muhammad RidloYuwono ${ }^{1 *}$, Tasari $^{1}$, Septiana Wijyanti ${ }^{1}$, I Wayan Angga Wijaya Kusuma ${ }^{2}$, Doni Setyawan $^{3}$, Syams Kurniawan Hidayat ${ }^{4}$}

\author{
${ }^{1}$ Prodi Pendidikan Matematika, FKIP, Universitas Widya Dharma Klaten, Indonesia \\ ${ }^{2}$ Prodi Teknik Elektro, Fakultas Teknik, Universitas Widya Dharma Klaten, Indonesia \\ ${ }^{3}$ Prodi Teknik Informatika, FakultasIlmuKomputer, Universitas Widya Dharma Klaten, Indoesia \\ ${ }^{4}$ Prodi ManajemenInformatika, FakultasIlmuKomputer, Universitas Widya Dharma Klaten, Indoesia \\ email: ridloyuwono90@ gmailcom ${ }^{1)}$;tasari_lutfi@yahoo.com ${ }^{1)}$; septiana.wijaya@ unwidha.ac.id ${ }^{1)}$; \\ anggaelectro@yahoo.com ${ }^{2)}$ donnisoft@gmail.com ${ }^{3)}$;awan2410@gmail.com ${ }^{4)}$
}

\begin{abstract}
Abstrak
Tujuan kegiatan pengabdian kepada masyarakat ini adalah untuk melatih guru-guru matematika SMP di Kabupaten Klaten agar dapat membuat dan mengembangkan video pembelajaran matematika yang interaktif dan konstruktif. Tim pengabdian mengajak kerja sama MGMP Matematika Kabupaten Klaten untuk melaksanakan kegiatan ini. Berdasarkan hasil suvei awal diperoleh bahwa masih sedikit guru matematika yang belum memanfaatkan dan mengembangkan video pembelajaran sebagai media pembelajaran yang interaktif dan konstruktif. Metode yang digunakan pada kegiatan pengabdian ini adalah pelatihan yang dilaksanakan secara tatap muka dan secara online melalui aplikasi Google Meet. Pertemuan I dilaksanakan secara tatap muka pada tanggal 5 Agustus 2020 di Fakultas Ilmu Komputer Universitas Widya Dharma Klaten. Pertemuan II, III dan IV dilaksanakan secara online pada 12, 19 dan 26 Agustus 2020. Hasil dari kegiatan pengabdian ini adalah guru mampu membuat dan mengembangkan media pembelajaran matematika dengan menggunakan aplikasi Ms. Power Point, merekam media pembelajaran tersebut dengan menggunakan aplikasi, menambahkan intro video pembelajaran dengan menggunakan aplikasi Intro Maker, dan menggabungkannya dengan menggunakan aplikasi BandiCut sehingga menjadi video pembalajaran matematika yang interaktif dan konstruktif. Kesimpulan dari kegiatan pelatihan ini adalah guru dapat membuat dan mengembangkan video pembelajaran matematika yang interaktif dan konstruktif.
\end{abstract}

\section{Kata kunci: interaktif; konstruktif; pelatihan; video pembelajaran}

\begin{abstract}
The purpose of this community service activity is to train junior high school mathematics teachers in Klaten so that they can create and develop interactive and constructive mathematics learning videos. The service team invites the Klaten MGMP Mathematics to work together to carry out this activity. Based on the results of the initial survey, it was found that there were still a few mathematics teachers who had not utilized and developed instructional videos as interactive and constructive learning media. The method used in this community service activity is training which is carried out face-to-face and online through the Google Meet application. Meeting I was held face-toface on August 5, 2020 at the Faculty of Computer Science, University of Widya Dharma Klaten. Meetings II, III and IV were held online on 12, 19 and 26 August 2020. The results of this service activity are that the teacher is able to create and develop mathematics learning media using the PowerPoint application, record the learning media using the Bandi Cam application, add learning
\end{abstract}


video intros using the Intro Maker application, and combine them using the BandiCut application so that it become an interactive and constructive mathematics learning video. The conclusion of this training activity is that techers can create and develop interactive and constructive mathematics learning videos.

\section{Keywords: constructive; interactive; instructional videos; training}

\section{PENDAHULUAN}

Sejak pertengahan bulan Maret 2020, pemerintah melalui Kementerian Pendidikan dan Kebudayaan telah menutup sekolah dikarenakan pandemi virus Covid-19. Bahkan sampai dengan akhir bulan Juli 2020 pandemi tersebut masih berlangsung dan jumlah yang terkonfirmasi positif terpapar virus Covid-19 semakin bertambah banyak hingga tembus angka 100.000 lebih.

Pemerintah mewajibkan sekolah untuk melaksanakan Pembelajaran Jarak Jauh (PJJ) dengan memanfaatkan platform digital secara online. Guru dituntut untuk dapat beradaptasi dengan model PJJ tersebut. Guru dan siswa harus menyiapkan peralatan yang mendukung pelaksanaan PJJ. Selain itu guru juga harus dapat mengembangkan perangkat pembelajaran yang selaras denga PJJ.

Materi pembelajaran yang biasanya bersifat tekstual harus dapat dikemas menjadi materi yang menarik dan mudah dipahami oleh siswa saat menerapkan PJJ. Apalagi untuk materi pada mata pelajaran matematika yang bersifat abstrak, sehingga memerlukan media yang tepat untuk menyampaikannya kepada siswa. Media pembelajaran matematika tersebut tentunya harus bersifat interaktif, artinya media tersebut mampu mengajak komunikasi siswa dengan menjawab pertanyaan-pertanyaan yang disajikan untuk menemukan suatu konsep atau rumus matematika. Selain itu, karena kurikulum yang berlaku saat ini adalah Kurikulum 2013, maka media pembelajaran tersebut juga harus bersifat konstruktif. Artinya, media pembelajaran tersebut harus memberikan fasilitas untuk siswa dalam mengonstruksi pengetahuan baru berdasarkan pengetahuan relevan yang pernah dipelajarinya.

Berdasarkan permasalahan tersebut, dosen Program Studi Pendidikan Matematika Universitas Widya Dharma Klaten berinisiatif untuk membantu guru-guru matematika di Kabupaten Klaten dalam menyiapkan media pembelajaran matematika yang interaktif dan konstruktif untuk mendukung pelaksanaan PJJ. Karena media pembelajaran tersebut memanfaatkan teknologi informasi dan komunikasi (TIK), maka dosen dari Fakultas Ilmu Komputer dan dosen dari Program Studi Teknik Elektro dilibatkan dalam kegiatan ini. Untuk memudahkan dalam berkomunikasi dan bekerja sama terkait kegiatan ini, maka dibentuk tim pengabdian kepada masyarakat unggulan Universitas Widya Dharma Klaten.

Supaya kegiatan ini tepat sasaran, tim pengabdian mengajak kerja sama MGMP Matematika SMP Kabupaten Klaten. Pada tanggal 27 Juli 2020, tim pengabdian mengadakan rapat dengan ketua MGMP Matematika SMP Kabupaten Klaten di SMP Negeri 1 Karanganom. Berdasarkan informasi yang diperoleh dari ketua MGMP tersebut, media pembelajaran yang dibutuhkan saat PJJ adalah video pembelajaran matematika.

Berikut beberapa hasil penelitian terkait dengan pengaruh video pembelajaran untuk pembelajaran matematika. Hasil penelitian Krisna dan Marga (2018) menyatakan bahwa video pembelajaran cukup efektif digunakan dalam kelas virtual matematika pada materi 
aljabar. Hasil penelitian Saman et al. (2019) menunjukkan bahwa video pembelajaran matematika membuat siswa mempunyai motivasi tinggi dalam belajar materi sistem persamaan linear dua variabel. Video pembelajaran dapat meningkatkan motivasi dan hasil belajar kognitif siswa (Suryansah \& Suwarjo, 2016).

Aplikasi yang digunakan untuk membuat video pebelajaran pada pelatihan ini adalah Ms. Power Point dan Bandi Cam. Ms. Power Point digunakan untuk membuat konten materi matematika yang konstruktif. Selain itu, Ms.Power Point juga digunakan untuk membuat animasi supaya materi yang disusun lebih interaktif ketika digunakan untuk belajar. Sementara aplikasi Bandi Cam digunakan untuk membuat video dengan cara merekam aktivitas Ms. Power Point tersebut ketika sedang dijalankan.

Untuk mendapatkan informasi yang valid terkait kemampauan guru matematika SMP di Kabupaten Klaten dalam mengembangkan media pembelajaran dengan memanfaatkan aplikasi Power Point dan Bandi Cam, tim pengabdian memberikan survei awal dengan menggunakan aplikasi Google Form. Survei awal tersebut diberikan kepada 22 guru matematika SMP yang tergabung dalam MGMP Matematika SMP Kabupaten Klaten.

Berdasarkan hasil survei awal tersebut diperoleh hasil bahwa: (1) hanya sekitar 13\% guru yang telah memanfaatkan Ms. Power Point dalam penerapan PJJ, (2) sekitar 4,3\% guru yang telah mengembangkan Ms. Power Point menjadi media yang menarik dan interaktif, (3) hanya sekitar $13 \%$ saja yang telah memanfaatkan video pembelajaran pada PJJ, (4) hanya sekitar 4,3\% saja yang telah mengembangkan video pembelajaran menjadi media pembelajaran matematika yang interaktif dan konstruktif.

Berdasarkan permasalahan tersebut, tim pengabdian dan MGMP Matematika sepakat untuk melaksanakan pelatihan membuat video pembelajaran matematika SMP yang interaktif dan konstruktif. Pelatihan tersebut ditujukan kepada guru matematika SMP di Kabupaten Klaten untuk mendukung implementasi PJJ pada mata pelajaran matematika SMP.

\section{METODE}

Metode yang digunakan pada pengabdian unggulan ini adalah pelatihan. Pelatihan dilaksanakan dalam 4 tahap. Tahap I dilaksanakan secara tatap muka di Fakultas Ilmu Komputer Universitas Widya Dharma Klaten, sedangkan tahap II, III dan IV dilaksanakan secara online dengan menggunakan aplikasi Google Meet. Tahap II, III dan IV dilaksanakan secara online karena masih dalam pandemi Covid-19. Tahap I dilaksanakan pada hari Rabu, 5 Agustus 2020. Tahap II dilaksanakan pada hari Rabu, 12 Agustus 2020 dengan membahas hasil video yang telah dibuat guru berdasarkan contoh yang telah diberikan. Dosen mereview hasil video tersebut untuk dilakukan perbaikan jika ada yang dinilai kurang. Tahap III dilaksanakan pada hari Rabu, 19 Agustus 2020 dengan materi pembuatan intro awal video pembelajaran menggunakan aplikasi Intro Maker dan penggabuangan video dengan menggunakan aplikasi Bandi Cut. Tahap IV dilaksanakan pada hari Rabu, 26 Agustus 2020 dengan membahas hasil video pembelajaran untuk materi lain yang sudah diberi intro maker. Pada tahap ini, dosen mereview hasil video tersebut untuk dilakukan perbaikan jika ada yang dinilai kurang.

Pada pertemuan terakhir peserta diminta untuk mengisi formulir evaluasi hasil pelatihan menggunakan aplikasi Google Form. Pertanyaan yang diberikan pada formulir 
tersebut berkaitan tentang: (1) apakah peserta sudah mampu membuat media pembelajaran matematika menggunakan Ms. Power Point; (2) apakah peserta sudah mampu merekam hasil media yang telah dibuat menggunakan aplikasi Bandi Cam menjadi sebuah video; (3) apakah peserta dapat membuat video pembelajaran untuk materi lainnya dan termotivasi untuk mengembangkannya.

\section{HASIL DAN PEMBAHASAN}

Pada pertemuan pertama peserta diberikan dua materi, yaitu cara membuat media pembelajaran matematika dengan memanfaatkan Ms. Power Point dan cara merekam hasil media pembelajaran yang telah dibuat dengan menggunakan aplikasi Bandi Cam untuk dibuat menjadi sebuah video pembelajaran. Dokumentasi kegiatan pada pertemuan I ditunjukkan pada Gambar 1.

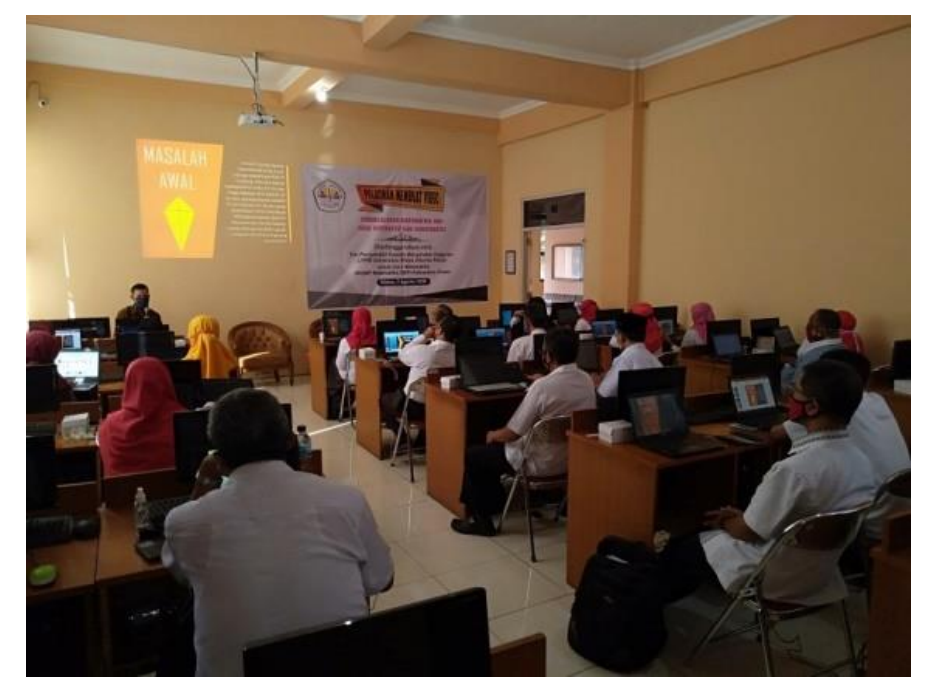

\section{Gambar 1. Pelaksanaan Pelatihan pada Pertemuan I}

Pertemuan kedua dilaksanakan pada hari Rabu (12 Agustus 2020) secara daring menggunakan aplikasi Google Meet. Kegiatan ini bertujuan untuk mereview hasil video pembelajaran yang telah dibuat berdasarkan contoh yang diberikan pada pertemuan pertama. Review dilakukan oleh dosen personil tim pengabdian. Berikut dua contoh hasil review terhadap video pembelajaran dari dua peserta, yaitu Bapak Amirudin dan Ibu Haryati. Hasil review terhadap video Bapak Amirudin adalah video tersebut sudah disusun dengan baik dan sudah sesuai dengan contoh yang diberikan. Akan tetapi, suaranya masih agak pelan, sehingga perlu diatur ulang settingan audionya. Hasil review terhadap video Ibu Haryati adalah video tersebut sudah disusun secara baik dan terdapat kreatifitas dalam pengembangan tampilannya. Akan tetapi, untuk kegiatan pendahuluan, kegiatan inti dan kegiatan penutup belum menyatu, sehingga perlu digabungkan menjadi satu. Ilustrasi kegiatan pada pertemuan kedua ditunjukkan pada Gambar 2. 


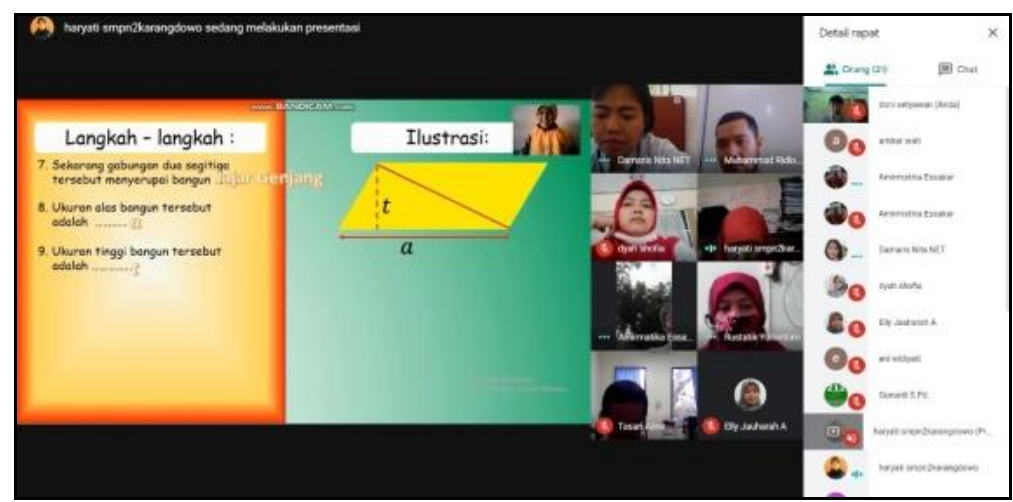

Gambar 2. Ilustrasi Kegiatan Pelatihan pada Pertemuan II

Pertemuan ketiga dilaksanakan pada hari Rabu (19 Agustus 2020) secara daring menggunakan aplikasi Google Meet. Tujuan kegitan pada pertemuan ketiga ini adalah untuk melatih peserta supaya dapat membuat intro video pembelajaran dengan menggunakan aplikasi Intro Maker dan menggabungkannya dengan video pembelajaran yang telah dibuat dengan menggunakan aplikasi Bandi Cut. Pada aplikasi Intro Maker, pengguna dapat: (1) memanfaatkan template video yang telah disediakan; (2) menyisipkan objek text, stiker, dan gambar beserta animasinya; (3) menyisipkan musik; serta (4) mengkonversinya menjadi sebuah video. Setelah penyampaian materi, terdapat tanya jawab yang interaktif antara pemateri dengan peserta. Ilustrasi kegiatan pada pertemuan ketiga ditunjukkan pada Gambar 3.

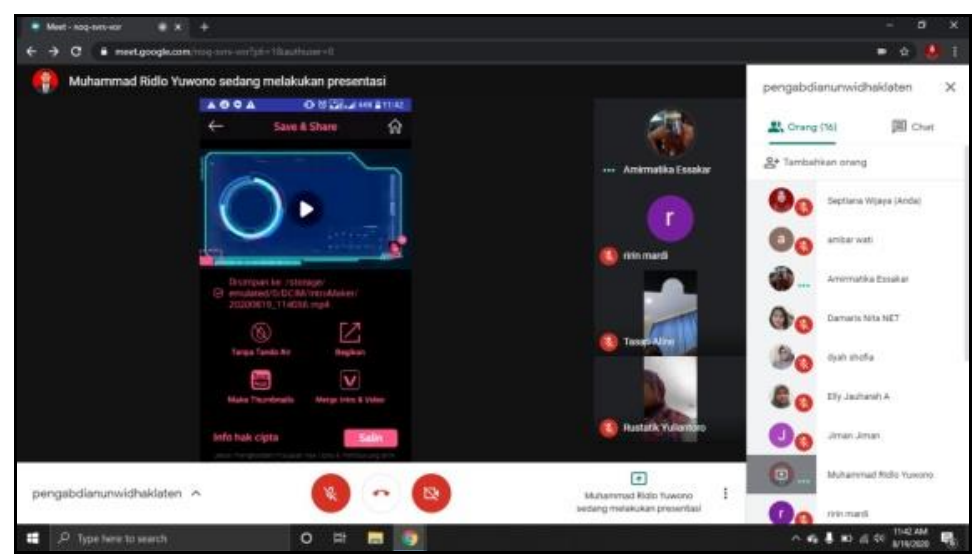

\section{Gambar 3. Ilustrasi Kegiatan Pelatihan pada Pertemuan III}

Pertemuan keempat dilaksanakan pada hari Rabu (26 Agustus 2020) secara daring dengan menggunakan aplikasi Google Meet. Tujuan kegiatan ini adalah mereview pengembangan hasil video pembelajaran untuk materi yang berbeda dengan materi yang terdapat pada pertemuan pertama. Sebagian besar peserta telah mampu mengembangkan video pembelajaran untuk materi yang berbeda. Pada video pembelajaran tersebut juga telah terdapat intro videonya. Video pembelajaran yang telah dikembangka peserta telah memenuhi kriteria interaktif dan konstruktif. Ilustrasi kegiatan pada pertemuan ketiga ditunjukkan pada Gambar 4. 


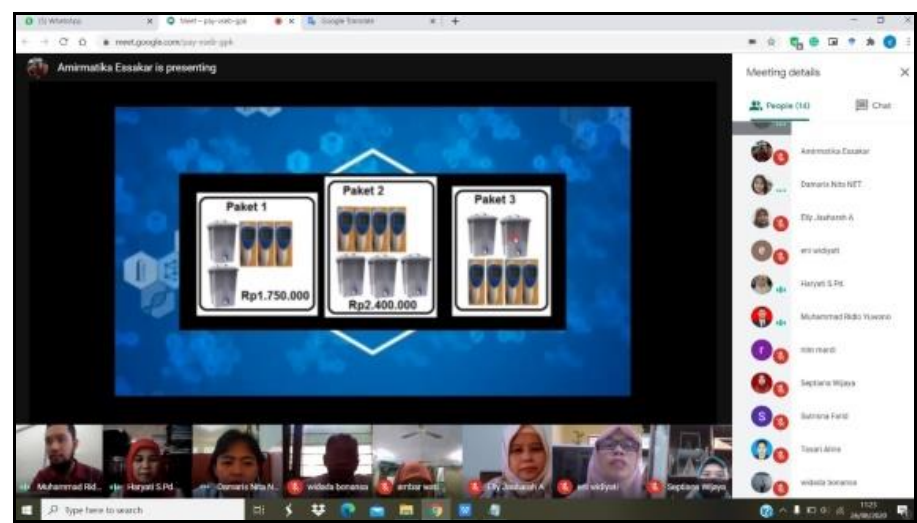

Gambar 4. Ilustrasi Kegiatan Pelatihan pada Pertemuan IV

Berdasarkan hasil evaluasi hasil pelatihan melalui aplikasi Google Form diperoleh informasi sebagai berikut. Peserta mampu membuat membuat media pembelajaran menggunakan apikasi Ms. Power Point. Peserta mampu merekam hasil media pembelajaran yang telah dibuat menggunakan aplikasi Bandi Cam. Sebagian besar peserta mampu membuat video pembelajaran untuk materi lain yang berbeda dengan materi yang dicontohkan. Sebagian besar peserta termotivasi untuk mengembangkan video pembelajaran untuk materi-materi yang lain guna mendukung implementasi pembelajaran jarak jauh.

Secara keseluruhan kegiatan pengabdian kepada masyarakat ini telah berjalan dengan lancar. Hal ini dikarenakan tiga faktor berikut. Faktor pertama adalah persiapan pelaksanaan kegiatan pengabdian ini telah disusun secara matang dan sistematis. Faktor kedua adalah adanya kerja sama yang baik di dalam anggota tim pengabdian ini. Faktor yang ketiga adalah adanya kerja sama yang baik antara Universitas Widya Dharma Klaten dengan MGMP Matematika SMP Kabupaten Klaten.

Selain tiga faktor tersebut, keberhasilan pelaksanaan kegiatan pengabdian masyarakat ini juga sejalan dengan keberhasilan pelaksanaan kegiatan pengabdian masyarakat yang relevan. Pelaksanaan kegiatan pelatihan pembuatan video pembelajaran dapat menambah pengetahuan bagi guru tentang tahapan membuat video pembelajaran (Mertha et al., 2019). Guru dapat membuat media pembelajaran matematika dengan menggunakan video based stud dan mengintregasikannya dalam perangkat pembelajaran setelah mengikuti pelatihan terkait media pembelajaran tersebut (Ekawati et al., 2016). Melalui pelatihan media pembelajaran yang inetraktif dan menarik, guru dapat mempunyai pengetahuan untuk mengoperasionalkan program untuk membuat media pembelajaran tersebut dan menjadikan guru lebih kreatif dalam mengembangkan media pembelajaran (Afrida et al., 2018).

\section{SIMPULAN}

Simpulan dari kegiatan pengabdian ini adalah guru mampu membuat dan mengembangkan video pembelajaran matematika yang interaktif dan konstruktif.

\section{UCAPAN TERIMA KASIH}

Ucapan terima kasih diberikan kepada Pusat Pengabdian Kepada Masyarakat Universitas Widya Dharma Klaten yang telah membiayai kegiatan ini. 


\section{DAFTAR PUSTAKA}

Afrida, A., Harizon, H., Bakar, A., \& Sanova, A. 2018. Pelatihan Pengembangan Media Pembelajaran Interaktif Berbasis Multimedia Sebagai Upaya Meningkatkan Kompetensi Profesionalisme dan Kreativitas Guru-Guru SMA Muaro Jambi. Jurnal Karya Abdi Masyarakat, 2(1), 15-22. https://doi.org/10.22437/jkam.v2i1.5426

Ekawati, R., Manuharawati, M., Palupi, E. L. W., \& Fardah, D. K. 2016. Pelatihan Pembuatan Media Pembelajaran Matematika Melalui Video-Based Stud. Jurnal ABDI, 1(2), 134. https://doi.org/10.26740/ja.v1n2.p130-134

Krisna, F. P. P., \& Marga, M. H. P. 2018. Pemanfaatan Video Untuk Pembelajaran Matematika Berbasis Masalah Kontekstual Pada Topik Aljabar| Krisna | Prosiding Seminar Nasional Pendidikan Matematika Etnomatnesia. Prosiding Seminar Nasional Pendidikan Matematika Etnomatnesia, 400-405. http://jurnal.ustjogja.ac.id/index.php/etnomatnesia/article/view/2354

Mertha, I. G., Rahayu, S., \& Lestari, N. 2019. Workshop Teknik Pembuatan Video Pembelajaran Pada Guru-Guru SMP N 1 Gunungsari Lombok Barat. Jurnal Pendidikan dan Pengabdian Masyarakat. Jurnal Pendidikan Dan Pengabdian Masyarakat, 2(1), 1-5. http://jurnalfkip.unram.ac.id/index.php/JPPM/article/view/990

Saman, S., Ma'rufi, M., \& Tiro, A. 2019. Pengembangan Video Pembelajaran Matematika Dalam Meningkatkan Minat dan Prestasi Belajar Siswa Pada Materi Persamaan Linear Dua Variabel. Pedagogy: Jurnal Pendidikan Matematika. PEDAGOGY, 4(1), 1-12. http://www.journal.uncp.ac.id/index.php/Pedagogy/article/view/1426

Suryansah, T., \& Suwarjo, S. 2016. Pengembangan Video Pembelajaran Untuk Meningkatkan Motivasi dan Hasil Belajar Kognitif Siswa Kelas IV SD. Jurnal Prima Edukasia, 4(2), 221. https://doi.org/10.21831/jpe.v4i2.8393 